\title{
IX. A numerical table of elective attractions; with remarks on the sequences of double decompositions
}

Thomas Young M.D. For. Sec. R.S.

To cite this article: Thomas Young M.D. For. Sec. R.S. (1809) IX. A numerical table of elective attractions; with remarks on the sequences of double decompositions, Philosophical Magazine Series 1, 34:135, 53-63, DOI: 10.1080/14786440908562924

To link to this article: http://dx.doi.org/10.1080/14786440908562924

Published online: 18 May 2009.

Submit your article to this journal $\pi$

山 Article views: 2

View related articles 
The Map that I am preparing, which traces every stream and vale up to its very origin, and shows its connection with the hard and soft, and porous and water-tight strata, and with the principal faults and tilts of the same, in its vicinity, will, as I trust, somewhat elucidate this difficult subject: on which I much wish to hear the observations of others of your able correspondents, and am,

Sir, your obedient humble servant,

Ram's Head Inn, Disley, Cheshire,

John Farey.

July $15,1809$.

* In our last vol. p. 263, line 1, the bases to should have been the babsets of three or four different strata \&c. Basset, crop, \&c., are mining terms for the out-burst or appearance of a stratum on the surface.

IX. A numerical Table of elective Attractions; with Remarks on the Sequences of double Decompositions. By Thomas Young, M.D. For. Sec. R.S.*

A a series of numbers, capable of representing the mutual attractive forces of the component parts of different salts; but these attempts have hitherto been confined within narrow limits, and have indeed been so hastily abandoned, that some very important consequences, which necessarily follow from the general principle of a numerical representation, appear to have been entirely overlooked. It is not impossible, that there may be some cases, in which the presence of a fourth substance, besides the two ingredients of the salt, and the medium in which they are dissolved, may influence the precise force of their mutual attraction, either by affecting the solubility of the salt, or by some other unknown means, so that the number, naturally appropriate to the combination, may no longer correspond to its affections; but there is reason to think that such cases are rare; and when they occur, they may easily be noticed as exceptions to the general rules. It appears, therefore, that nearly all the phænomena of the mutual actions of a hundred different salts may be correctly represented by a hundred numbers, while, in the usual

* From Philosophical Transactions for 1809, Part I.

D 3

manner 
manner of relating every case as a different experiment, above two thousand separate articles would be required.

Having been engaged in the collection of a few of the principal facts relating to chemistry and pharmacy, I was induced to attempt the investigation of a series of these numbers; and I have succeeded, not without some difficulty, in obtaining such as appear to agree sufficiently well with all the cases of double decompositions which are fully established, the exceptions not exceeding twenty, out of about twelve hundred cases enumerated by Fourcroy. The same numbers agree in general with the order of simple elective attractions, as usually laid down by chemical authors; but it was of so much less importance to accommodate them to these, that I have not been very solicitous to avoid a few inconsistencies in this respect, especially as many of the bases of the calculation remain uncertain, and as the common tables of simple elective attractions are certainly imperfect, if they are considered as indicating the order of the independent attractive forces of the substances concerned. Although it cannot be expected that these numbers should be accurate measures of the forces which they represent, yet they may be supposed to be tolerable approximations to such measures; at least, if any two of them are nearly in the true proportion, it is probable that the rest cannot deviate very far from it: thus, if the attractive force of the phosphoric acid for potash is about eight tenths of that of the sulfuric acid of barita, that of the phosphoric acid for barita must be about nine tenths as great; but they are calculated only to agree with a certain number of phænomena, and will probably require many alterations, as well as additions, when all other similar phænomena shall have been accurately investigated.

There is, however, a method of representing the facts, which have served as the bases of the determination, independently of any hypothesis, and without being liable to the contingent necessity of any future alteration, in order to make room for the introduction of the affections of other oubstances; and this method enables us also to compare, 
upon general principles, a multitude of scattered phænomena, and to reject many which have been mentioned as probable, though doubtful, with the omission of a very few only which have been stated as ascertained. This arrangement simply depends on the supposition, that the attractive force, which tends to unite any two substances, may always be represented by a certain constant quantity.

From this principle it may be inferred, in the first place, that there must be a sequence in the simple elective attractions. For example, there must be an error in the common tables of elective attractions, in which magnesia stands above ammonia under the sulfuric acid, and below it under the phosphoric, and the phosphoric acid stands above the sulfuric under magnesia, and below it under ammonia, since such an arrangement implies, that the order of the attractive forces is this; phosphate of magnesia, sulfate of magnesia, sulfate of ammonia, phosphate of ammonia, and again phosphate of magnesia; which forms a circle, and not a sequence. We must therefore either place magnesia above ammonia under the phosphoric acid, or the phosphoric acid below the sulfuric under magnesia; or we must abandon the principle of a numerical representation in this particular case.

In the second place, there must be an agreement between the simple and double elective attractions. Thus, if the fluoric acid stands above the nitric under barita, and below it under lime, the fluate of barita cannot decompose the nitrate of lime, since the previous attractions of these two salts are respectively greater, than the divellent attractions of the nitrate of barita and the fluate of lime. Probably, therefore, we ought to place the fluoric acid below the nitric under barita; and we may suppose, that when the fluoric acid has appeared to form a precipitate with the nitrate of barita, there has been some fallacy in the experiment.

The third proposition is somewhat less obvious, but perhaps of greater utility: there must be a continued sequence in the order of double elective attractions; that is, between any two acids, we may place the different bases in such an order, that any two salts, resulting from their union, shall 
always decompose each other, unless each acid be united to the base nearest to it: for example, sulfuric acid, barita, potass, sorla, ammonia, strontia, magnesia, glycina, alumina, zirconia, lime, phosphoric acid. The sulfate of potass decomposes the phosphate of barita, because the difference of the attractions of barita for the sulfuric and phosphoric acids is greater than the difference of the similar attractions of potass ; and in the same manner the difference of the attractions of potass is greater than that of the attractions of soda ; consequently the difference of the attractions of barita must be much greater than that of the attractions of soda, and the sulfate of soda must decompose the phosphate of barita : and in the same manner it may be shown, that each base must preserve its relations of priority or posteriority to every other in the series. It is also obvious that, for similar reasons, the acids may be arranged in a continued sequence between the different bases; and when al! the decompositions of a certain number of salts have been investigated, we may form two corresponding tables, one of the sequences of the bases with the acids, and another of those of the acids with the different bases; and if either or both of the tables are imperfect, their deficiencies may often be supplied, and their errors corrected, by a repeated comparison with each other.

In forming tables of this kind from the cases collected by Fourcroy, I have been obligéd to reject some facts, which were evidently contradictory to others, and these I have not thought it necessary to mention: a few, which are positively related, and which are only inconsistent with the principle of numericai representation, I have mentioned in notes; but many others, which have been stated as merely probable, 1 have omitted without any notice. In the table of simple elective attractions; I have retained the usual order of the different substances; inserting again in parentheses such of them as require to be transposed, in order to avoid inconsequences in the simple attractions: I have attached to each combination marked with an asterisc the number deduced from the double decompositions, as expressive of its attractive force; and where the number is inconsistent with the corrected 
corrected order of the simple elective attractions, I have also inclosed it in a parenthesis. Such an apparent inconsistency may perbaps in some cases be unavoidable, as it is possible that the different proportions of the masses concerned, in the operations of simple and compound decomposition, may sometimes cause a real difference in the comparative magnitude of the attractive forces. Those numbers, to which no asterisc is affixed, are merely inserted by interpolation, and they can only be so far employed for determining the mutual actions of the salts to which they belong, as the results which they indicate would follow from the comparison of any other numbers, intermediate to the nearest of those, which are more correctly determined. I have not been able to obtain a sufficient number of facts relating to the metallic salts, to enable me to comprehend many of them in the tables.

It has been usual to distinguish the attractions, which produce the double decompositions of salts, into necessary and superfuous attractions; but the distinction is neither very accurate, nor very important: they might be still further divided, accordingly as two, three, or the whole of the four ingredients concerned are capable of simply decomposing the salt in which they are not contained; and if two, accordingly as they are previously united or separate; such divisions would however merely tend to divert the attention from the natural operation of the joint forces concerned.

It appears to be not improbable, that the attractive force of any two substances might, in many cases, be expressed by the quotient of two numbers appropriate to the substances, or rather by the excess of that quotient above unity; thus the attractive force of many of the acids for the three principal alkalies might probably be correctly represented in this manner; and where the order of attractions is different, perhaps the addition of a second, or of a second and third quotient, derived from a different series of numbers, would afford an accurate determination of the relative force of attraction, which would always be the weaker, as the two Gubstances concerned stood nearer to each other in these orders 
orders of numbers; so that, by affixing, to each simple substance, two, three, or at most four numbers only, its attractive powers might be expressed in the shortest and most general manner.

I have thought it necessary to make some alterations in the orthography generally adopted by chemists, not from a want of deference to their individual authority, but because it appears to me that there are certain rules of etymology, which no modern author has a right to set aside. According to the orthography universally established throughout the language, without any material exceptions, our mode of writing Greek words is always borrowed from the Romans, whose alphabet we have adopted: thus the Greek vowel $\Upsilon$, when alone, is always expressed in Latin and in English by $Y$, and the Greek diphthong or by $U$, the Romans having no such diphthong as OU or OY. The French have sometimes deviated from this rule; and if it were excusable for any, it would be for them, since their $u$ and $o u$ are pronounced exactly as the $\Upsilon$ and or of the Greeks probably were : but we have no such excuse. Thus the French have used the term acoustique, which some English authors have converted into "acoustics;" our anatomists, however, speak, much more correctly, of the "acustic" nerve. Instead of glucine, we ought certainly, for a similar reason, to write glycine; or glycina, if the names of the earths are to end in $a$. Barytes, as a single Greek word, means weight, and must be.pronounced bárytes; but as the name of a stone, arcented on the second syllable, it must be written barites ; and the pure earth may properly be called barita. Yttria I have altered to itria, because no Latin word begins with a $Y$. 
of elective Attractions.

急

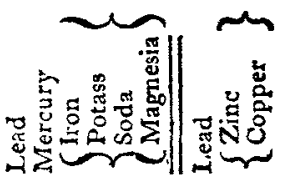

吾

$\frac{2}{3}$

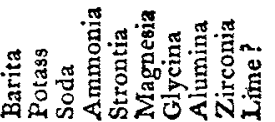

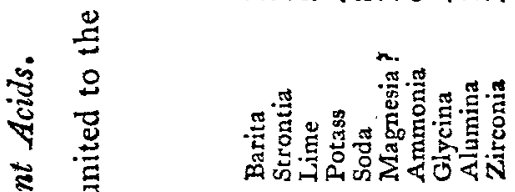
6

क्षे

\&

$\underset{i}{\infty} \frac{\pi}{\pi}$

永

过 总

लि की

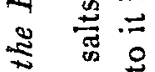

分

岕 岁营

号

$\stackrel{0}{0}$

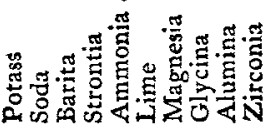

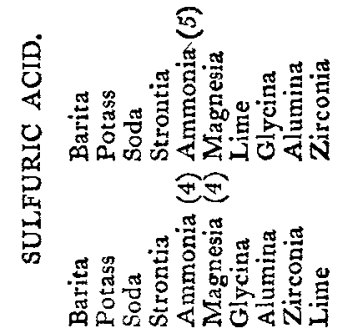

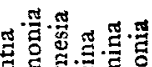

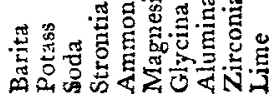

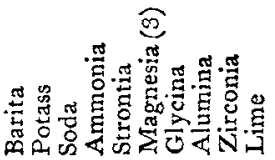

\section{$\approx \overparen{\mathrm{\sigma}} \approx$}

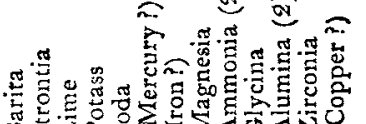

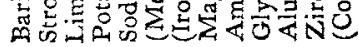

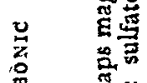

o. 占范

空究

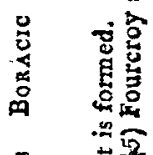

2.

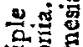

空最

४ है

斗若

농

记

昰高

可觜

屰

要超

范

要

荧

象䨔

范完

品

少

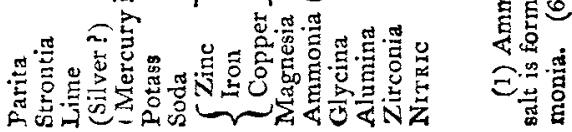




\begin{tabular}{|c|c|c|c|c|c|}
\hline $\begin{array}{l}\text { NITRIC } \\
\text { ACID. }\end{array}$ & \multicolumn{5}{|c|}{ NITRIC AND MURIATIC ACIDS. } \\
\hline Barita & Potuss & Barita & Potas: & Barita (10) & Pot ass \\
\hline Potass & Soda & Potass & Soda & Potass & Soda \\
\hline Soda & Ammonia & Soda & Ammonia & Soda & Barita (10) \\
\hline Struntia & Magnesia & Ammonia & Magnesia & Ammonia & Ammonia $(\tau, 11)$ \\
\hline Lime & Glycina & Magnesia & Glycina & Magnesia & Magnesia $(\tau)$ \\
\hline Magnesia (n) & Alumina & Glycina & Alumina & Glycina & Strontia \\
\hline Ammonia (i) & Zirconia (8) & Alumina & Zirconia & Alumina & Lime \\
\hline Glycina & Barita & Zirconia & Barita & Zirconia & Glycina \\
\hline Alumina & Strontia & Strontia (9) & Strontia & Strontia & Alumina \\
\hline Zirconia & Lime & Lime & Lime & Lime & Zirconia \\
\hline Muruatic & Phosphorxic & Fudonyc & SuLFurous & Boracic & Carbonic \\
\hline
\end{tabular}

(7) A triple salt is formed. (8) Fourcroy says, that the muriate of zirconia decomposes the phosphates of barita and strontia. (9) According to Fourcroy's account, the fluate of strontia decomposes the muriates of ammonia, and of all the bases below it; but he ways in another part of the same volume, that the fuate of strontia is an unknown salt. (10) According to Fourcroy's account of these combinations, barita should atand immediately below ammonia in both of these columns. (11) With heat, the carbonate of lime decomposes the muriate of ammonia.

PHosphoRrC ACL.

\begin{tabular}{|c|c|c|c|c|}
\hline $\begin{array}{l}\text { Barita } \\
\text { Lime } \\
\text { Potmos } \\
\text { Soda } \\
\text { Strontia } \\
\text { Magnesia } \\
\text { Ammonia } \\
\text { Glycina } \\
\text { Alumina } \\
\text { Xirconia } \\
\text { Fudoric }\end{array}$ & $\begin{array}{l}\text { Lime } \\
\text { Barita } \\
\text { Potass } \\
\text { Soda } \\
\text { Strontia } \\
\text { Magnesia } \\
\text { Ammonia } \\
\text { Glycina } \\
\text { Alumina } \\
\text { Zirconia } \\
\text { Sulfunous }\end{array}$ & $\begin{array}{l}\text { Barita } \\
\text { Lime } \\
\text { Potass } \\
\text { Soda } \\
\text { Strontia } \\
\text { Ammonia (12) } \\
\text { Magnesia } \\
\text { Glycína } \\
\text { Alumina } \\
\text { Zirconia } \\
\text { Borscic }\end{array}$ & $\begin{array}{l}\text { Potasa } \\
\text { Soda } \\
\text { Barita } \\
\text { Lime (18) } \\
\text { Strontia } \\
\text { Ammonia } \\
\text { Magnesia } \\
\text { Glycina } \\
\text { Alumina } \\
\text { Zirconia } \\
\text { CARBoní }\end{array}$ & $\begin{array}{l}\text { Barita } \\
\text { Lime } \\
\text { Potass } \\
\text { Soda } \\
\text { Strontia } \\
\text { Magnesia } \\
\text { Glycina? } \\
\text { Alumina } \\
\text { Zirconia }\end{array}$ \\
\hline
\end{tabular}

(12) According to Fourcroy, the phosphate of anmonia decomposes the borate of magnesia. (13) Fourcroy says, that the carbonate of lime decomposes the phosphates of potass and of soda.

FLUORIC ACID.

$\begin{array}{lll}\text { Lime } & \text { Lime } & \text { Potass } \\ \text { Potass } & \text { Barita } & \text { Soda } \\ \text { Soda } & \text { Strontia } & \text { Lime } \\ \text { Magnesia } & \text { Potass } & \text { Barita } \\ \text { Ammonia } & \text { Soda } & \text { Strontia } \\ \text { Glycina } & \text { Ammonia } & \text { Ammonia(14) } \\ \text { Alumina } & \text { Magnesia } & \text { Magnesia } \\ \text { Zirconia } & \text { Glycina } & \text { Glycina } \\ \text { Strontia } & \text { Alumina } & \text { Alumina } \\ \text { Barita } & \text { Zirconia } & \text { Zirconia } \\ \text { SuLfurous } & \text { BopAcic } & \text { CARBonic }\end{array}$

(14) According to Fourcroy, the carbonate of ammonia decomposes the fluater of barita and strontia. 


\section{SURFUROUS ACID.}

Barita

Strontia

Potass

Soda

Ammonia

Magnesia

Lime

Glycina

Alumina

Zirconia

Boracic

$\begin{array}{ll}\text { Potass } & \text { Lime } \\ \text { Soda } & \text { Strontia } \\ \text { Barita (15) } & \text { Barita } \\ \text { Strontia } & \text { Zirconia } \\ \text { Ammonia } & \text { Alumina } \\ \text { Lime } & \text { Glycina } \\ \text { Magnesia } & \text { Magnesia } \\ \text { Glycina } & \text { Ammonia } \\ \text { Alumina } & \text { Soda } \\ \text { Zirconia } & \text { Potass } \\ \text { Carzonic } & \text { (Nrmous) }\end{array}$

Zirconia

Alumina

Glycina

Ammonia

Magnesia

Strontia

Soda

Potase

Barita

Lime

(Phosprorous i)
BORACIC ACID.

Potass

Soda

Iime

Barita

Strontia

Magnesia

Ammonia

G) ycina

Alumina

Lirconia

Canbosic

(15) Fourcroy says, that the sulfite of barita decomposes the carbonate of ammoniax

Talle of the Sequences of the Acids with different Bases.

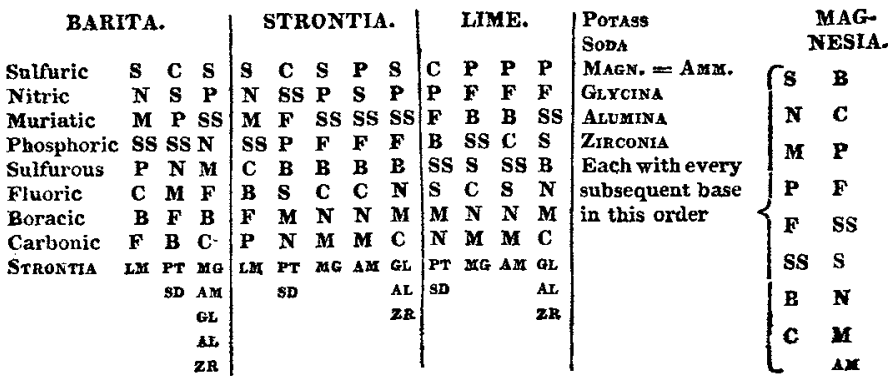

The comparative use of this table may be understood from an example: If we suppose that the nitrate of barita decompošes the borate of ammonia, we must place the boracic acid above the nitric, between barita and ammonia in this table, and consequently barita below ammonia, between the fluoric and boracic in the former: hence the boracic and fluoric acids must also be transposed between barita and strontia, and between barita and potass; or if we place the fluoric still higher than the boracic in the first instance, we must place barita below ammonia between the nitric and fluoric acids, where indeed it is not impossible that it ought to stand. 
Numerical Table of elective Attractions.

\begin{tabular}{|c|c|c|c|c|c|c|c|c|}
\hline \multicolumn{2}{|c|}{ BARTA- } & \multicolumn{2}{|c|}{ STRONTIA. } & \multicolumn{2}{|l|}{ Porass. } & SoDA. & \multicolumn{2}{|l|}{ LinE, } \\
\hline sulfuric acid & $1000 *$ & Sulfuric acid & $903 *$ & Sulfuric ac & & & Oxalic acid & 960 \\
\hline xalic & 950 & Phosphoric & $827 *$ & & $894^{*}$ & * $885 *$ & Sulfuric & $868^{*}$ \\
\hline uccinie & 930 & Oxalic & $\mathbf{8 e 5}$ & Nitric & $812^{*}$ & * $804^{*}$ & Tartaric & 867 \\
\hline Fluoric & & Tartaric & 757 & Muriatic & $804^{*}$ & * $797 *$ & Succinie & 866 \\
\hline hosphoric & $906 *$ & Fluorte & & Phosphoric & $803^{*}$ & * 795* & Phosphoric & $865 *$ \\
\hline Mucic & 900 & Nitric & $754^{*}$ & Saberic ? & 745 & 740 & Mucic & 860 \\
\hline Nitric & $849 *$ & Muriatic & $748 *$ & Fluoric & $671 *$ & * $666^{*}$ & Nitric & $741 *$ \\
\hline Iariatic & 840 * & (Succinic) & 740 & Oxalic & 650 & 645 & Muriatic & $736 *$ \\
\hline uberic & 800 & (Fluoric) & $603 *$ & Tartarie & 616 & 611 & Suberic & 735 \\
\hline Cütric & & Succinic & & Arsenic & 614 & 609 & Fluoric & $734 *$ \\
\hline Tentaric & 760 & Citric? & 618 & Succinic & 612 & 607 & Arsenic & 733 \\
\hline rsenic & $733 \frac{x}{2}$ & Lactic & 603 & Citric & 610 & 605 & Lactic & 732 \\
\hline (Citric) & 730 & sulfurous & $327 *$ & Lactic & 609 & 604 & Citric & 731 \\
\hline Lactic & 729 & Acetic & & Benzuic & 608 & 603 & Malic & 700 \\
\hline Rlaoric) & $706 *$ & Arsenic & $\left(783 \frac{\pi}{4}\right)$ & Stufturous & $488^{*}$ & 484* & Benzoic & 590 \\
\hline oic & 597 & Bor & $513^{*}$ & Acetic & 486 & 482 & Acetic & \\
\hline cetic & 594 & (Acetic) & 480 & Muc & 484 & 480 & Boracic & $537 *$ \\
\hline oracte & $(515)^{*}$ & Nitrous? & 430 & Borac & $482 *$ & $479^{*}$ & Sulfurous & $516 *$ \\
\hline Iffurous & 593* & Carbonic & $419^{*}$ & Nitrous & 440 & 437 & (Acetic) & 470 \\
\hline & 450 & & & Carbonic & $306^{*}$ & 304* & Nitrous & 425 \\
\hline arbonic & $480 *$ & & & Prussic & 300 & 298 & Cartonie & $423 *$ \\
\hline nesic & 400 & & & & & & Prussic & 290 \\
\hline
\end{tabular}

Magnera.

Ammonts.

Glygina :

Alumina. Zircosxia:

Oxalle acid

Phosphoric

Sulfaric

820 Sulfuric acid Nitric

810* Muriatic

(Phosphoric)

Fluoric

Arsenic

Mucic

Succintc

Nitric

Muriatic

Suberic?

(Fluoric)

Tartaric

Citric

Malic?

Lactic

Benzoic

Acetic

Boracic

Sulfurouts

786 * Phosphoric

Suberic?

733 Fluoric

732종 Oxalic

732 Tartaric

782 * Arsenic

728 * Succinie

700 Citric

680 * Lactic

618 Bentoic

615 Sulfurous

600? Acetic

675 Mucic

560 Boracie

459* Carbonic

439* Prussic

808* Sulfuric acid
$791 *$ Nitric

729* Murjatic

728* Oxalic

720 Arsenic

613* Staberic?

611 Fluoric

609 Tartaric

607 Succinic

605 Mucic

608 Citric

601 Phosphoric

599 Lactic

433* Benzoic

432 Acetic

431 Boracic

430 * Sulfurous

400 Nitrous

339* Carbonic

270 Prussic

$\begin{array}{cll}718^{*} & 709^{*} & 700^{*} \\ 642^{*} & 634^{*} & 626^{*} \\ 639^{*} & 632^{*} & 625^{*} \\ 600 & 594 & 588 \\ 580 & 575 & 570 \\ 535 & 530 & 525 \\ 534^{*} & 529^{*} & 524^{*} \\ 520 & 515 & 510 \\ 510 & 505 & 500 \\ 425 & 420 & 415 \\ 415 & 410 & 406 \\ (648)^{*} & (642)^{*} & 6636)^{*} \\ 410 & 405 & 460 \\ 400 & 395 & 390 \\ 395 & 391 & 387 \\ 388 * & 385^{*} & 388^{*} \\ 355 * & 351^{*} & 347^{*} \\ 340 & 336 & 338 \\ 325 * & 323^{*} & 321^{*} \\ 960 & 258 & 256\end{array}$

(Acotic)

480

Nitrous

Carbonic

410

Prussic

66 *

280

Acids.

\begin{tabular}{|c|c|c|c|c|c|c|c|}
\hline SuLFut & & Nitar & & Murtat & & Phospao & Rtc. \\
\hline & $1000^{*}$ & Barita & $849 *$ & Barita & $840^{*}$ & Barifa & $90 \varepsilon^{*}$ \\
\hline & $903 *$ & Potass & $812^{*}$ & Potass & $804 *$ & Strontia & $82 \% *$ \\
\hline & $894^{*}$ & Soda & 804* & Soda & $797 *$ & Lime & $(865)^{\text {th }}$ \\
\hline & $885^{*}$ & Strontia & $754^{*}$ & Strontia & $748^{*}$ & Potass & $801^{*}$ \\
\hline & $868 *$ & Lime & $741^{*}$ & Lime & $736^{*}$ & Soda & $795 *$ \\
\hline nesia & $810^{*}$ & Magnesia & $732 *$ & Ammonia & $729 *$ & Ammonia & $(728)^{*}$ \\
\hline onia & $808^{*}$ & Ammonia & $731 *$ & Magnesia & 728* & Magnesia & $736 *$ \\
\hline & $718 *$ & Glycina & $642^{*}$ & Glycina & $639 *$ & Glycina & $648 *$ \\
\hline & 712 & Alumina & $634 *$ & Alumina & $632^{*}$ & Alumina & $642 *$ \\
\hline & 709* & Zirconia & 626* & Zirconia & $625^{*}$ & Zirconia & $636 *$ \\
\hline & $200 *$ & & & & & & \\
\hline
\end{tabular}




\begin{tabular}{lrllll}
\multicolumn{2}{c}{ Fivonic. } & \multicolumn{2}{c}{ Oxalic. } & \multicolumn{2}{c}{ TARTARro } \\
time & $734^{*}$ & Lime & 960 & 867 \\
Barita & $706^{*}$ & Barita & 950 & 760 \\
Strontia & $703^{*}$ & Strontia & 825 & 757 \\
Magnesia & $(620)^{*}$ & Magnesia & 820 & 618 \\
Potass & $671^{*}$ & Potass & 650 & 616 \\
Soda & $666^{*}$ & Soda & 645 & 611 \\
Ammonia & $613^{*}$ & Ammonia & 611 & 609 \\
Glycina & $534^{*}$ & Glycina? & 600 & 520 \\
Alumina & $599^{*}$ & Alumina & 594 & 515 \\
Zirconia & $524^{*}$ & Zirconia & 588 & 510
\end{tabular}

Succinic.

Barita 930

Lime 866

Strontia ? 740

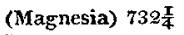

Potass 612

Soda 607

Ammonia 605

Magnesia

Glycina? 510

Alumina 505

Zirconia? 500

\begin{tabular}{lc}
\multicolumn{2}{c}{ LACTic. } \\
Barita & 789 \\
Potass & 609 \\
Soda & 604 \\
Strontia & 603 \\
Lime & $(732)$ \\
Ammonia & 601 \\
Magnesia & 575 \\
Metallic oxids \\
Glycina & 410 \\
Alumina & 405 \\
Zirconia & 400
\end{tabular}

BeNzorc.

White oxide of arsenic

Potass 608

Soda 603

Ammonia 599

Barita 597

Lime 590

Magnesia 560

Glycina? 400?

Alumina 395

Zirconia? 390 ?

\begin{tabular}{llll}
\multicolumn{2}{c}{ Mucre? } & \multicolumn{2}{c}{ Boracic. } \\
Barita & 900 & Lime & $537^{*}$ \\
Lime & 860 & Barita & $515^{*}$ \\
Potass & 484 & Strontia & $513^{*}$ \\
Soda & 480 & Magnesia & $(459)^{*}$ \\
Ammonia & 431 & Potass & $482^{*}$ \\
Glycina & 495 & Soda & $479^{*}$ \\
Alumina & 420 & Ammonia & $430^{*}$ \\
Zirconia & 415 & Glycina & $388^{*}$ \\
& & Alumina & $385^{*}$ \\
& & Zirconia & $382^{*}$
\end{tabular}

\begin{tabular}{ll}
\multicolumn{2}{c}{ ARSENIC. } \\
Lime & $\mathbf{7 8 3}$ \\
Barita & $733 \frac{3}{2}$ \\
Strontia & $733 \frac{\text { t }}{4}$ \\
Magnesia & 733 \\
Potass & 614 \\
Soda & 609 \\
Ammonia & 607 \\
Glycina & $\mathbf{5 8 0}$ \\
Alumina & $\mathbf{5 7 5}$ \\
Zirconia & $\mathbf{5 7 0}$
\end{tabular}

Camrhoric.

Lime

Potass

Soda

Barita

Ammonia

Glycina ?

Alumina

Zirconia

Magnesia

Sur.ruhous.

$\begin{array}{lr}\text { Barita } & 592^{*} \\ \text { Lime } & 516 * \\ \text { Potass } & 486^{*} \\ \text { Soda } & 484^{*} \\ \text { Strontia } & (527)^{*} \\ \text { Magnesia } & 439 * \\ \text { Ammonia } & 433^{*} \\ \text { Glycina } & 355 * \\ \text { Alumina } & 351 * \\ \text { Zirconia } & 347 *\end{array}$

Nitroes ?

$\begin{array}{ll}\text { Barita } & \mathbf{4 5 0} \\ \text { Potass } & \mathbf{4 4 0} \\ \text { Soda } & \mathbf{4 3 7} \\ \text { Strontia } & \mathbf{4 3 0} \\ \text { Lime } & \mathbf{4 2 5} \\ \text { Magnesia } & \mathbf{4 1 0} \\ \text { Ammonia } & \mathbf{4 0 0} \\ \text { Glycina } & \mathbf{8 4 0} \\ \text { Alumina } & \mathbf{3 3 6} \\ \text { Zirconia } & 339\end{array}$

Texastre.

Lime

Barita

Strontia

Magnesia

Potass

Soda

Ammonia

Glycina

Alumina

Zirconia

\begin{tabular}{ll}
\multicolumn{2}{c}{ Crrric. } \\
Lime & 731 \\
Barita & 730 \\
Strontia & 618 \\
Magnesia & 615 \\
Potass & 610 \\
Soda & 605 \\
Ammonia & 603 \\
Glycina? & $415 ?$ \\
Alumina & 410 \\
Zirconia & 405
\end{tabular}

Careonic.

$\begin{array}{lcll}\text { Barita } & 420^{*} & \text { Barita } & \mathbf{4 0 0} \\ \text { Strontia } & 419^{*} & \text { Strontia } & \\ \text { Iime } & (423)^{*} & \text { Potass } & \mathbf{3 0 0} \\ \text { Potass : } & 306^{*} & \text { Soda } & 293 \\ \text { Soda } & \mathbf{3 0 4}^{*} & \text { Lime } & 290 \\ \text { Magnesia } & \left(\mathbf{3 6 6 ) ^ { * }}\right. & \text { Magnesia } & 280 \\ \text { Ammonia } & 339^{*} & \text { Ammonia } & 270 \\ \text { Glycina } & 395^{*} & \text { Glycina? } & 260 \\ \text { Alumina } & 323^{*} & \text { Alumina? } & 258 \\ \text { Zirconia } & 321^{*} & \text { Zirconia? } & 956\end{array}$

Phosphorods.

Lime

Barita

Strontia

Potass

Soda

Magnesia?

Ammonia

Glyeina

Alumina

Zireonia 